\title{
The Influence of Liquidity, Profitability and Leverage on Profit Management and Its Impact on Company Value in Manufacturing Company Listed on Indonesia Stock Exchange Year 2011-2015
}

\author{
Ayu Mulyana ${ }^{1}, Z^{\prime}$ uraida $^{2}$, Mulia Saputra ${ }^{3, "}$ \\ ${ }^{1}$ Master economic and businees faculty, syiah Kuala University \\ ${ }^{2,3}$ Economic and Businees Faculty, Syiah Kuala University \\ *Corresponding Author: Mulia Saputra, Economic and Business faculty, syiah Kuala University, \\ Indonesia
}

\begin{abstract}
This study examines the effect of likuidity, profitability, and leverage on earnings management and its impact on the value of the company. The study uses hypothesis testing on secondary data obtained from corporate website and the official website of the indonesia stock exchange. The firm-year observation of this study consists of 150 manufacturing companies listed on the indonesia stock exchange from the period of 2011-2015. The result show that liquidity, profitability, and leverage jointly affect earnings management; liquidity, profitability, and leverage individually affect earning management; liquidity, profitability, leverage and earnings management together affect company value; liquidity, profitability, leverage and earnings management individually affect company value; earning management partially mediates the effect of liquidity, profitability, and leverage on company.
\end{abstract}

Keywords: Likuididitas, Profitability, Leverage, Earnings management, enterprise value

\section{INTRODUCTION}

The Company is a unit of production activity that processes economic resources to provide goods and services for the community to gain profit and satisfy the needs of society. Wahyudi and Pawestri (2006), the company's main objective is to increase the value of the company. The higher the value the company describes the more prosperous the owner. The increase in corporate value is always accompanied by an increase in corporate profits. Directly increase in profits will prosper the owner. The company's value can be seen from the price to book value (PBV). PBV is a value that can be used to compare whether a stock is more expensive or cheaper than other stocks. According to Ahmed and Nanda (2004) in Jefriansyah (2013), almost all investment decisions in the capital market are based on the development of the PBV. High PBV will make investors believe in the company's future prospects. The amount of PBV cannot be separated from the policies taken by the company. One of the factors that may affect the value of the company is earnings management (earnings management). Earnings management is a condition in which the management to intervene in the process of preparation of financial statements for external parties so as to flatten, raise, and lower earnings (Schipper, 2012 in Ningsaptiti, 2010). Scott (2003) defines profit management as an action made through the choice of accounting policies to obtain certain goals, for example, to meet its own interests or increase the market value of the company. Managers tend to do more earnings management by controlling accrual transactions, ie transactions that do not affect cash flow (Friedlan, 1994). While on the other hand, investors also tend to concentrate in the income statement as investors found earnings stability will affect the stability of dividends.

Profitability is the company's ability to generate profits. Profit is often a measure of company performance, where when a company has a high profit means it can be concluded that the company's performance is good and vice versa. Income smoothing is one form of earnings management. Managers tend to do the activity because with low profits or even suffering losses, will worsen the performance of managers in the eyes of the owner and will worsen the company's image in 
the public eye.Husni(2011), shows that profitability has a positive effect on earnings management. In the research of Ershad (2008) concluded that the profitability of the company does not significantly affect the practice of income smoothing (earnings management).

Leverage is debt used by the company to finance its assets in order to carry out its operational activities. The greater the company's debt the greater the risk faced by the owner so that the owner will ask for higher profit levels so that the company is not threatened in liquidation. If a company is threatened with liquidation then the immediate action that management might take is profit management. By doing earnings management, the company's performance will look good in the eyes of shareholders and the public even though the company is in danger of being liquidated. In research Widyaningdyah (2001) concluded that leverage has a significant effect on earnings management. Unlike the case with research conducted by Irsyad (2008) which concluded that leverage does not significantly affect the practice of income smoothing (earnings management).

Liquidity is the company's ability to pay short-term financial obligations just in time (Sartono, 2011). Companies that have high liquidity levels will provide a picture of the company able to meet its short-term obligations. Such circumstances make investors will be interested in investing capital to distribute profits in the form of dividends. According to Sartono (2001) liquidity has a direct relationship with the dividend policy where the greater the liquidity of a company will be the greater the company's ability to pay dividends, This is in line with research conducted by Andriyani (2008), Mohammed et al (2008), Diana (2009), Mehta (2012), Wicaksana (2012) and Adnyana and Badjra (2014) which states that liquidity is positive and significant effect on the dividend policy. Different from the results expressed by Griffin (2010), Franklin and Muthusamy (2010), Sunarto andKartika (2003) and Kapoor (2009) that the liquidity negatively affects dividend policy.

From the data obtained showed the same phenomenon, namely the decrease in the value of the company in all the sample companies from 2011 until 2015. The ups and downs of the value of the company into a phenomenon that interesting to talk about, this is related to the growth of the company itself.

\section{RESEARCH METHODS}

This research uses causality design. The design of causality is useful for measuring the strength of the relationship between two or more variables. This study is hypothesis testing using secondary data obtained from the official website of the stock exchange or corporate website with www.idx.co.id. The population in this research is manufacturing companies listed on the stock exchange from 20112015 , with sampling based on predetermined criteria. The number of samples in this study were 30 companies multiplied by 5 years of observation so that the number of sample of this research was 150 .

\section{RESULTS AND DISCUSSION}

\subsection{Classic Assumption Testing}

Testing assumption classic does for determining model regression can be received on a regular basis econometrics. Testing assumption classic this composed from testing normality, heteroscedasticity, and multicollinearity. The assumption test results initially occur symptoms of classical assumptions. Due to this, the data that has been tabulated in Ln first to eliminate the classical assumption symptoms. After the data in Ln, the data already Ln re-done the classical assumption test. Results will not happen again the classical assumption of normality test, heteroscedasticity, and multicollinearity.

\subsection{Test Results Correlation}

Results test Correlation explains there whether or not the relationship between variables the one with other variables. Test correlation between variable in research this could seen on Table 4. 1.

Table4. 1. Results Test Correlation

\begin{tabular}{|c|c|c|c|}
\hline No. & Relationship between Variables & Value & Information \\
\hline 1. & $\mathrm{X} 1$ and Y & 0.006 & No connection \\
\hline 2. & $\mathrm{X} 2$ and Y & 0.154 & Positive less powerful \\
\hline & $\mathrm{X} 3$ and Y & 0.196 & Positive less powerful \\
\hline 3. & $\mathrm{Y}$ and Z & 0.283 & Positive less powerful \\
\hline 4. & $\mathrm{X} 1$ and Z & 0.134 & Positive less powerful \\
\hline 5. & $\mathrm{X} 2$ and Z & 0.403 & Positive is \\
\hline & $\mathrm{X} 3$ and Z & 0.573 & Positive is strong \\
\hline
\end{tabular}

Source: Data processed 2017 
The Influence of Liquidity, Profitability and Leverage on Profit Management and Its Impact on Company Value in Manufacturing Company Listed on Indonesia Stock Exchange Year 2011-2015

Based on Table 4.6 could noted that existence relationship the strong one between liquidity $\left(\mathrm{X}_{1}\right)$ with profit management $(\mathrm{Y})$ of 0.006 which means liquidity $\left(\mathrm{X}_{1}\right)$ not related to earnings management $(\mathrm{Y})$, the relationship is between profitability $\left(\mathrm{X}_{2}\right)$ with earnings management $(\mathrm{Y})$ of 0.154 which means that the profitability of $\left(\mathrm{X}_{2}\right)$ is related less strongly with earnings management $(\mathrm{Y})$, leverage $\left(\mathrm{X}_{3}\right)$ with earnings management $(\mathrm{Y})$ amounted to 0.196 meaningful leverage $\left(\mathrm{X}_{3}\right)$ has a less strong relationship with earnings management $(\mathrm{Y})$.

Profit management $(\mathrm{Y})$ with firm value $(\mathrm{Z})$ of 0.283 which means that earnings management $(\mathrm{Y})$ has the less strong relationship with firm value $(\mathrm{Z})$. Liquidity $\left(\mathrm{X}_{1}\right)$ with the value of the company $(\mathrm{Z})$ of 0.134 meaningful liquidity $\left(\mathrm{X}_{1}\right)$ has a less strong positive relationship with the enterprise value $(\mathrm{Z})$. Profitability $\left(\mathrm{X}_{2}\right)$ the value of the company $(\mathrm{Z})$ of 0.403 has a meaning that profitability $\left(\mathrm{X}_{2}\right)$ has a positive relationship with the company's medium $(\mathrm{Z})$. While leveraging $\left(\mathrm{X}_{3}\right)$ with the value of the company $(\mathrm{Z})$ of 0.573 which means that the leverage $\left(\mathrm{X}_{3}\right)$ have a strong positive relationship with the enterprise value $(\mathrm{Z})$

\subsection{Results Test Mediation}

Results test mediation could seen from linkages coefficient path between mediation model as it is that presented on Table 4. 2.

Table4. 2. Results Test Mediation

\begin{tabular}{|l|l|l|l|l|}
\hline Regression & Coefficient XI & Coefficient X2 & Coefficient X3 & Information \\
\hline II & $0.031 *$ & $0.137 *$ & $0.190 *$ & $\begin{array}{l}\text { Mediation applies perfectly if the regres- } \\
\text { sion coefficient value II <regression I }\end{array}$ \\
\hline III & $0.207 * *$ & $0.330 * *$ & $0.555^{*} *$ & $*$ \\
\hline
\end{tabular}

* The value of beta coefficient obtained from the table Regression I

** The value of the beta coefficients obtained from the regression table II

Source: data processed, 2017

Based on Table 4. 2 could is known that value coefficient which are contained in regression II all larger of the in regression I. This shows that earnings management is not apply perfect as variable mediation (intervening) for influence liquidity, profitability, and leverage against the value of the company.

\subsection{Hypothesis Testing Substructure I}

The results of hypothesis testing are shown in Table as follows:

Table. Regression Result

\begin{tabular}{|c|c|c|c|c|c|c|}
\hline \multicolumn{2}{|c|}{ Model } & \multicolumn{2}{|c|}{ Unstandardized Coefficients } & Standardized Coefficients & \multirow{2}{*}{ t } & \multirow{2}{*}{ Sig. } \\
\cline { 3 - 6 } \multicolumn{2}{|c|}{} & B & Std. Error & Beta & & \\
\hline \multirow{4}{*}{1} & (Constant) & $-3,503$ &, 321 & & -10.914 &, 000 \\
\cline { 2 - 7 } & Liquidity (X1) &, 059 &, 157 &, 031 &, 377 &, 707 \\
\cline { 2 - 7 } & Profitability (X2) &, 142 &, 083 &, 137 & 1,699 &, 092 \\
\cline { 2 - 7 } & Leverage (X3) &, 175 &, 075 &, 190 & 2,324 &, 021 \\
\hline
\end{tabular}

Big coefficient residue for $\varepsilon_{1} \sqrt{1}-R^{2}=\sqrt{1}-0,242=\sqrt{0,758}=0,871$. With There obtained equation for substructure $\mathrm{I}$. That is $\mathrm{Y}=0,031 \mathrm{X}_{1}+0,137 \mathrm{X}_{2}+0,190 \mathrm{X}_{3}+0,871 \varepsilon_{1}$.

\subsection{Hypothesis Testing Substructure II}

For test hypothesis substructure II could do by counting value coefficient path that used from results processing data by using SPSS as it is presented on Table 4. 5 .

Tabe14. 5. Coefficients Substructure II

\begin{tabular}{|c|c|c|c|c|c|c|}
\hline \multicolumn{2}{|c|}{ Model } & \multicolumn{2}{c|}{ Unstandardized Coefficients } & Standardized Coefficients & \multirow{2}{*}{ t } & \multirow{2}{*}{ Sig. } \\
\cline { 2 - 6 } \multicolumn{2}{|c|}{} & B & Std. Error & Beta & & \\
\hline \multirow{4}{*}{1} & (Constant) & 2,324 &, 361 & & 6,441 &, 000 \\
\cline { 2 - 7 } & Liquidity (X1) &, 460 &, 131 &, 207 & 3,522 &, 001 \\
\cline { 2 - 7 } & Profitability (X2) &, 394 &, 070 &, 330 & 5,607 &, 000 \\
\cline { 2 - 7 } & Leverage (X3) &, 591 &, 064 &, 555 & 9,244 &, 000 \\
\cline { 2 - 7 } & Earnings management(Y) &, 140 &, 069 &, 122 & 2.034 &, 044 \\
\hline
\end{tabular}

a. Dependent Variable: company value $(Z)$

Source: Data processed 2017 
Big coefficient residue for $\varepsilon_{2} \varepsilon_{2}$ adalahadalah $\sqrt{1}-R^{2}=\sqrt{1}-0,513=\sqrt{0,606}=0,698$. With so obtained equation for substructure II that is $\mathrm{Z}=0,207 \mathrm{X} 1+0,330 \mathrm{X}_{2}+0,555 \mathrm{X}_{3}+0.122 \mathrm{Y}+0.698 \varepsilon_{2}$.

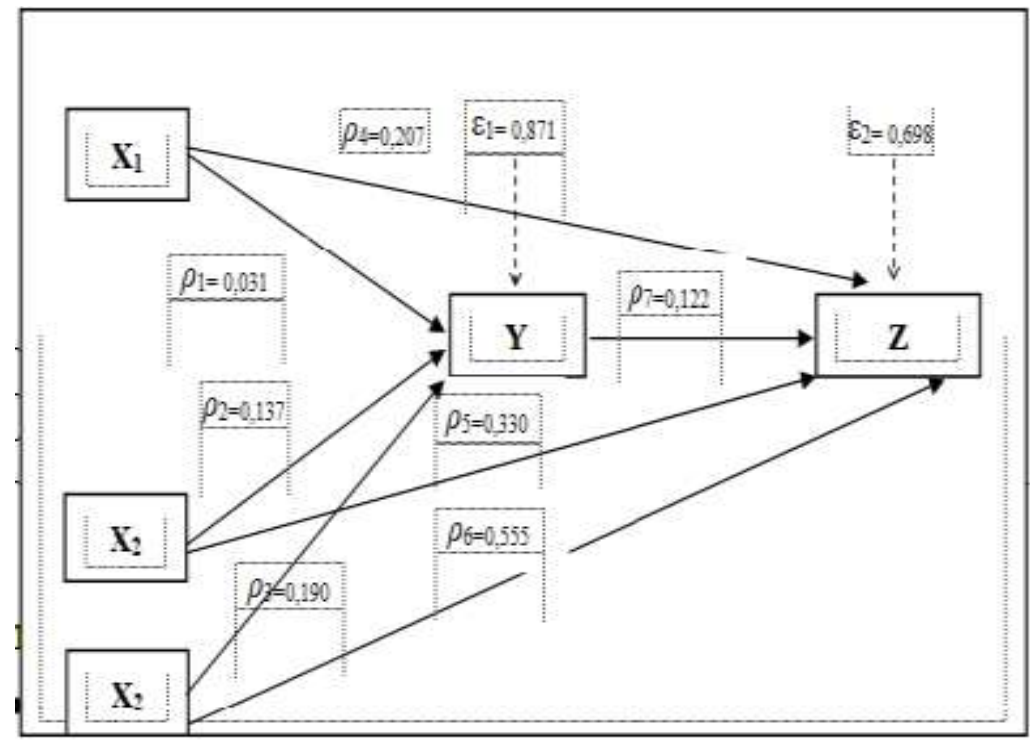

Fig. Model research from results structural testing complete.

\subsection{The Influence of Liquidity, Profitability and Leverage is together to Earnings Management}

The results of the first hypothesis testing is Ha be accepted. this means that the liquidity $\left(\mathrm{X}_{1)}\right.$, profitability $\left(\mathrm{X}_{2)}\right.$, and leverage $\left(\mathrm{X}_{3}\right.$ ) jointly effect on earnings management $(\mathrm{Y})$. The determination criterion is based on value coefficient $\rho$ lane ${ }_{1}\left(\mathrm{X}_{1} \rightarrow \mathrm{Y}\right), \quad \rho_{2}\left(\mathrm{X}_{2} \rightarrow \mathrm{Y}\right)$ or $\rho_{3}\left(\mathrm{X}_{3} \rightarrow \mathrm{Y}\right) \neq 0$, that is $0.031,0.137$ and 0.190 . Variables profit management that could explained by the variable independent liquidity, profitability, and leverage together is of 5.9\%;

\subsection{The Influence of Liquidity to Earnings Management}

Results testing hypothesis second is Ha be accepted. This means that liquidity (X 1) take effect to profit management $(\mathrm{Y})$. Criteria determination based by value coefficient path $\rho 1(\mathrm{X} 1 \rightarrow \mathrm{Y}) \neq 0$, is 0,031 . The magnitude influence variable $\mathrm{X} 1 \mathrm{Y}$ is $(0,031) 2 \times 100 \%=0.091 \%$;

\subsection{The Influence of Profitability to Earnings Management}

Results testing hypothesis third is Ha be accepted. P it means that profitability (X2) take effect to earnings management $(\mathrm{Y})$. Criteria determination based by value coefficient path $\rho 2(\mathrm{X} 2 \rightarrow \mathrm{Y}) \neq 0$, ie 0.137. The magnitude influence variable $\mathrm{X} 2$ to variable $\mathrm{Y}$ is (0.137) $2 \times 100 \%=1.88 \%$.

\subsection{The Influence of Leverage to Earnings Management}

Results testing hypothesis fourth is Ha be accepted. P this means that leverage (X 2) effect on earnings management $(\mathrm{Y})$. Criteria determination based by value coefficient $(\mathrm{Y})$. $\rho 3(\mathrm{X} 3 \rightarrow \mathrm{Y})$ $\neq 0$, ie 0.190 . The magnitude influence variable $\mathrm{X} 3$ to variable $\mathrm{Y}$ is $(0.184) 2 \mathrm{x} 100 \%=3.61 \%$.

\subsection{The Influence of Liquidity, Profitability, Leverage and Earnings Management is together to Company Value}

Results testing hypothesis fifth is Ha be accepted. This means liquidity, profitability, leverage and earnings management on together take effect of company value. Criteria determination is based by path coefficient value $\rho 4(\mathrm{X} 1 \rightarrow \mathrm{Z})$ or $\rho 5(\mathrm{X} 2 \rightarrow \mathrm{Z})$ or $\rho 6(\mathrm{X} 3 \rightarrow \mathrm{Z})$ or $\rho 7(\mathrm{Y} \rightarrow \mathrm{Z}) \neq 0$ that is $0.207,0.330,0.555$, and 0.122 . The variable of the company's value can be explained by variable liquidity, profitability, leverage and earnings management on together is as big 51.3\%;

\subsection{The Influence of Liquidity to Company Value}

Results testing hypothesis sixth is Ha be accepted. $\rho$ it means that liquidity effect to company value. Criteria determination based by value path coefficient $\rho_{4}\left(X_{1} \rightarrow Z\right) \neq 0$, that is 0.207 . The magnitude influence variable $\mathrm{X}_{1}$ to variable $\mathrm{Z}$ is $(0.207)^{2} \times 100 \%=4.28 \%$; 
The Influence of Liquidity, Profitability and Leverage on Profit Management and Its Impact on Company Value in Manufacturing Company Listed on Indonesia Stock Exchange Year 2011-2015

\subsection{The Influence of Profitability to Company Value}

This means that profitability take affect to company value. Criteria determination based by value path coefficient $\rho 5(\mathrm{X} 2 \rightarrow \mathrm{Z}) \neq 0$, that is 0.330 . The magnitude influence variable $\mathrm{X} 2$ variable $\mathrm{Z}$ is $(0.330) 2 \times 100 \%=10.89 \%$;

\subsection{The Influence of Leverage to Company Value}

Test result hypothesis eight is Ha be accepted. This means that leverage (X3) take effect to company value $(Z)$. Criteria determination based by value path coefficient $\rho 6(X 3 \rightarrow Z) \neq 0$, that is 0.555 . The magnitude influence variable $\mathrm{X} 3 \mathrm{Z}$ is $(0.555) 2 \times 100 \%=30.80 \%$;

\subsection{The Influence of Earnings Management to Company Value}

Results testing hypothesis ninth is Ha beaccepted. This matter means that earnings management (Y) take effect to company value ( $\mathrm{Z}$ ). Criteria determination based by value path coefficient $\rho 7(\mathrm{Y} \rightarrow \mathrm{Z}) \neq 0$, namely -0.093 . The magnitude influence variable $\mathrm{Y}$ against the variable $\mathrm{Z}$ is $(0.122) 2 \times 100 \%=1.49 \%$.

\subsection{The Earnings Management Mediates the Effect of the Liquidity on Company Value}

Results testing hypothesis tenth is Ha beaccepted. This means that the earnings management (Y)mediates the effect of liquidity (X 1) against company value (Z).Criteria determination is based by path coefficient value $\rho 1(\mathrm{X} 1 \rightarrow \mathrm{Y}) \neq 0$, or $\rho 7(\mathrm{Y} \rightarrow \mathrm{Z}) \neq 0,0.031$ and 0.122 . Value $(\rho 1 \times \rho 7) \leq \rho 4=\leq 0.00380 .207$, then $Y$ mediates partially the effect of $X 1$ to $Z$. management partially mediates the effect of liquidity on the value of the company;

\subsection{The Earnings Management Mediates the Effect of the Profitability on Company Value}

The results of the eleventh hypothesis testing are $\mathrm{Ha}$ accepted. This means that the earnings management mediates the effect of profitability to firm value. Criteria determination based by value coefficient path $\rho 2(\mathrm{X} 2 \rightarrow \mathrm{Y}) \neq 0$ or $\rho(\mathrm{Y} \rightarrow \mathrm{Z}) \neq 0$, that is 0.137 and 0.122 . Value $(\mathrm{P} 2 \times \rho 7) \leq \rho 5$ $=\leq 0.0170 .330$, then $Y$ mediate on partially the effect of $X 2$ to Z. Earnings management partially mediates the effect of profitability on the value of the company.

\subsection{The Earnings Management Mediates the Effect of the Leverage on Company Value}

The result of hypothesis testing of twelve is Ha accepted. This means that the earnings management (Y) mediates the effect of leverage (X3) to firm value (Z). Criteria determination is based by value coefficient path $\rho 3(\mathrm{X} 3 \rightarrow \mathrm{Y}) \neq 0$ or $\rho 7(\mathrm{Y} \rightarrow \mathrm{Z}) \neq 0$, namely 0.190 and 0.122 . Value $(\mathrm{P}$ $2 \times \rho 7) \leq \rho 6=\leq 0.0230 .555$, then $Y$ mediate on partially the effect of $X 3$ to $Z$. Earnings management partially mediates the effect of leverage on the value of the company.

\section{CONClusion}

Based on the results research that obtained and the discussion, then it can take conclusion as following: 1). Liquidity, profitability, and leverage jointly effect on earnings management ; 2). Liquidity effect on earnings management; 3). Profitability take effect to earnings management; 4). Leverage effect on earnings management; 5). Liquidity, profitability, leverage and earnings management together take effect to use values $\mathrm{p}$ company; 6). Liquidity effect company value; 7). Profitability take effect on company value; 8). Leverage take to effect company value; 9). Profit management take effect on the enterprise value; 10 . Earnings management partially mediate the effect of liquidity against company value; 11). Management earnings partially mediate the effect of profitability to firm value; 12). Management earnings partially mediate the effect of leverage to firm value.

\section{REFERENCES}

[1] Adnyana, I Gede, Ida BagusBadjra 2014. "Effect of Liquidity, Asset Management, EPD and Dividend Policy Against Company size and value of the company" E-Journal of Management, University of Udayana Vol.3 \# 12. 3707-3724.

[2] Afriani, Fillya. Safitri, Ervita. Aprilia, Rini. 2014. Influence of liquidity, leverage, profitabiitas, company size and growth of the dividend policy. Journal of STIE MDP, Palembang. It 1-15.

[3] Andriyani, Maria. 2008. Influence Analysis of Cash Ratio, Debt to Equity Ratio, Insider Ownership, Investment Opportunity Set (IOS), and Profitability To Dividend Policy.Thesis. Master Program Management of Postgraduate Program of Diponegoro University, Semarang. 
The Influence of Liquidity, Profitability and Leverage on Profit Management and Its Impact on Company Value in Manufacturing Company Listed on Indonesia Stock Exchange Year 2011-2015

[4] Aritta, Rini, 2004, Influence of Liquidity, Underwriting Obligation, Profitability and Leverage of Financial Value of Dividend Per Share (DPs) at Manufacturing Company in JSE, Thesis Faculty of Economics, University of Riau: Pekanbaru.

[5] Brigham, Eugene F, and Joel F, Houston. 2010. The basics of financial management. Book 1. Issue 11. Interpretation aliakbaryulianto. Jakarta: Salemba Four.

[6] Diana, Nur. 2009. The Influence of Financial Performance on Dividend Policy in Consumer Goods Industries listed on Indonesia Stock Exchange. Journal Scientific Business Economics.

[7] Dira, KadekPrawisanti\& Ida Bagus Putra Astika. 2014. Effect of Capital Structure, Liquidity, Income Growth, And Company Size On Profit Quality. Vo. 7, No. 1. 64-78.

[8] Franklin John and Muthusamy. 2010. Leverage, Growth, and Profitability as Determinants of Dividend Payout Ratio-Evidence from Indian Paper Industry. Asian Journal of Business Maagement Studies 1 (1): p: 26-30.

[9] Friedlan, John M. 1994. Accounting Choices of issuers of Initial Public Offerings . Contemporary Accounting Research, Vol.11, Summer 1994, 131.

[10] Guna, Welvin, I, and HerawatyHarleen, 2010. Effect of Good Corporate Governance Mechanisms, independency Auditor, Audit Quality, and Other Factors Against Profit Management. Journal of Business and Accounting, Vol. 12, No.1, Page 53-68.

[11] Gunawan, I Ketut, Nyoman Ari Surya Darmawan, I GustiAyuPurnamawati. 2015. Effects of Company Size, Profitability, And Leverage Against Profit Management In Manufacturing Companies Listed on the Indonesia Stock Exchange (BEI). E -Journal S1 Ak Ganesha University of Education . Vol. 3, No. 1.. 110

[12] Hanafi, Mamduh. M and Abdul Halim. 2007. Analysis of the financial statements. The third edition. Yokyakarta: UPP STIM YKPN.

[13] Horne V. James and John M Wachowicz. 2012. Principles of Financial Management (Fundamentals of Financial Management). 12. Issue Translated by DewiFitriasari. Jakarta: Four Salemba.

[14] Husni, Raudhatul. 2012. Influence Mechanism of Good Corporate Governance, Leverage And Profitability Of Earnings Management in Real Estate And Property Company Listed on the Indonesia Stock Exchange. Thesis. Andalas University.

[15] Jefriansyah. 2014. " Effect of debt policy and management at the company's earnings to the value of companies listed on the Stock Exchange". UNP.

[16] Kapoor, Sujata. 2009. Impact of Dividend Policy On Shareholders' Value. Jaypee Institute of Information Technology, Noida, India ,pp: 02-39.

[17] KomangAyuNovita Sari, LuhKomangSudjarni. 2015. "Effect of Liquidity, Leverage, Growth, Profitability Of Dividend Policy In Manufacturing Companies Listed in Indonesia Stock Exchange Year 2011-2013" E-Journal of Management Udayana University. Vol.4, No. 10, 3346-3374.

[18] Mehta, Anupam, (2012), " An empirical analysis of determinants of dividend policy evi-dence from the UAE companies ," Global Review of Accounting and Finance.

[19] Mohamed, N., Hui, WS, Omar, N., Rahman, RA, Mastuki, N., Aziz, MAA, and Zakaria, S. 2008. Empirical Analysis Of Determinants Of Dividend Payment: Profitability And Likuidity. Accounting Research Institute and Faculty of Accountancy, pp: 01-20.

[20] Ningsaptiti, Restie. 2010. Effect Analysis Company Size and Corporate Governance Mechanism Against Profit Management. Semarang. Diponegoro University.

[21] Nuriaina 2005, anlisis Effect of Free Cash Flow, Investment Opportunity Set and Leverage to Profit Management in Manufacturing Companies listed on the Jakarta Stock Exchange, Thesis Faculty of Economics, University of Riau Pekanbaru.

[22] Sartono, Agus. 2010. Financial management (theory and applications). Fourth edition, Yogyakarta: BPFE.

[23] Scott, William R. 2003. Financial Accounting Theory 3rd edition.Pearson Education Canada.

[24] Suharli, Michell. 2006. Empirical Study Of Factors Affecting the Company's Corporate Value Go Public in Indonesia . Journal of Management Accounting, 6 (1): p: 23-24.

[25] Sunarto and Kartika, A. 2003. Analysis of Factors Affecting Cash Dividend in the Jakarta Stock Exchange. Journal of Business and Economics. Vol. 1, 1, 1-16.

[26] Sudjoko and Soebiantoro. 2007. Effect of Shareholding, Laverage, ektern Factor FactorAgainst Internal and Corporate Values (Emperik Study On Manufacturing Company in Jakarta Stock Exchange). In the Journal of Management and Entrepreneurship, 9 (1): p: 41-48. 
The Influence of Liquidity, Profitability and Leverage on Profit Management and Its Impact on Company Value in Manufacturing Company Listed on Indonesia Stock Exchange Year 2011-2015

[27] Tarjo. 2008. Effect of Institutional Ownership Concentration and Leverage to Profit Management, Shareholder Value and Cost of Equity Capital. Accounting National Symposium XI, Pontianak.

[28] Wahyudi, Untung and Prasetyaning, HartiniPawestri. 2005. "Implications of Ownership Structure Against Corporate Value: The Financial Decisions As an intervening variable". Accounting National Symposium IX . Padang August 23 to 26.

[29] Wicaksana, I GedeAnanditha. 2012. Effect of Cash Ratio, Debt to Equity Ratio and Return On Assets Of Dividend Policy On Manufacturing Company in Indonesia Stock Exchange.Thesis. Post Graduate Program Udayana University, Denpasar.

[30] Widyaningdyah, Agnes Utari. 2001. Analysis of Factors - Factors That Influence Of Earnings Management on the company to go public in Indonesia. Journal of Accounting and Finance, Vol. 3, 2 , 89-101.

[31] Widyastuti, Tri. 2009. "The Effect of Ownership Structure and Financial Performance Against Profit Management: Study on Manufacturing Company on the Stock Exchange ". MaksiJournal, Volume 9, No. 1, p. 30-41.

[32] KR Subramanyam John J. Wild, Hasley Robert F. 2005. Financial Statement Analysis, Issue 8, Salemba Four, Jakarta.

[33] Yuli WS, Kurniati. 2010. Factors Affecting Earnings Quality in Manufacturing Company in Indonesia Stock Exchange. Essay. Faculty of Economics, University of Muhammadiyah Surakarta.

[34] Yushita, Amanita Novi, Rahmawati\&ahnungTriatmoko. Influence Mechanism of Corporate Governance, Quality External Auditor, And Liquidity on the Quality of Earnings. Journal Economia. Vol. 9, No. 2. 141-155.

Citation: Ayu Mulyana, Zuraida, Mulia Saputra. "The Influence of Liquidity, Profitability and Leverage on Profit Management and Its Impact on Company Value in Manufacturing Company Listed on Indonesia Stock Exchange Year 2011-2015 "International Journal of Managerial Studies and Research (IJMSR), vol 6, no. 1, 2018, pp. 8-14. doi:http://dx.doi.org/10.20431/2349-0349.0601002.

Copyright: () 2018 Authors. This is an open-access article distributed under the terms of the Creative Commons Attribution License, which permits unrestricted use, distribution, and reproduction in any medium, provided the original author and source are credited. 